Running Head: Acute Ketamine Experience and Psychiatric Outcomes

\title{
Ketamine as a mental health treatment: are acute psychoactive effects associated with outcomes? A systematic review
}

Meryem Grabski $^{1,2}$, Anya Borissova ${ }^{1,3}$, Beth Marsh $^{1,2}$, Celia J. A. Morgan ${ }^{2}$, H. Valerie Curran ${ }^{1}$

1. Clinical Psychopharmacology Unit, University College London, 1-19 Torrington Place, London WC1E 7HB, UK

2. Psychopharmacology and Addiction Research Centre, University of Exeter, Perry Road, Prince of Wales Road, Exeter, EX4 4QG, UK

3. NIHR University College London Hospitals Biomedical Research Centre, University College Hospital, Maple House, 149 Tottenham Court Road, London W1T 7DN, UK

\section{Word count: 4118}

Current Address Corresponding Author: Meryem Grabski, Clinical Psychopharmacology Unit, Department of Psychology and Language Science, 1-19 Torrington Place, London WC1E6BT, UK. Email:m.grabski@ucl.ac.uk 


\begin{abstract}
Esketamine was recently licensed by the US Food and Drug Administration (FDA) and European Drug Agency (EDA) for use in treatment resistant depression (TRD), and promising research indicates ketamine as a possible treatment in other mental health conditions. While the underlying mechanisms remain unclear, it has been hypothesized that acute psychoactive effects during ketamine administration may be associated with psychiatric treatment efficacy. We systematically reviewed the evidence for this association. The databases Medline, Embase and PsychInfo were searched up to June 2019. Studies were included if they enrolled adults with a psychiatric diagnosis, assessed acute psychoactive effects using a quantitative measure, and reported on the relationship between acute effects and treatment outcome. We included 21 studies, involving 891 patients. Seventeen studies assessed patients with depression (TRD [k=14]), three assessed substance use disorders, and one assessed social anxiety disorder. Overall, 41 associations were assessed, of which $26 \%$ were significant. The studies reviewed displayed great variability in terms of methodology and quality of reporting. The most commonly assessed effect was dissociation, measured by the CADSS. Our results suggest that the CADSS total is not consistently associated with antidepressant outcomes. Apart from this, the current literature is too limited to draw definite conclusions on the presence of an association between acute psychoactive effects and mental health outcomes. The field would benefit from consistently employing a priori hypotheses, more transparent reporting and sufficiently powered statistical analyses. Furthermore, the use of a broader range of assessments tools of acute psychoactive effects during ketamine administration would be beneficial.
\end{abstract}

Key words: review, ketamine, mental health, psychotomimetic effects, dissociative effects, psychedelic effects, mystical experience 


\section{Ketamine as a mental health treatment: are individual differences in drug experience associated with outcomes? A systematic review}

\section{Introduction}

Esketamine, an analogue of the glutamate N-methyl-D-aspartate (NMDA) receptor antagonist ketamine, has recently been approved by the Food and Drug Administration (FDA) of the United States and the European Drug Agency (EDA) as a pharmacotherapy for treatment resistant depression (TRD). Despite much research supporting the antidepressant effects of subanaesthetic doses of ketamine, and some research into other mental health conditions such as generalized anxiety disorder (1), obsessive compulsive disorder (2), and substance use disorders $(3,4)$ the mechanisms underpinning these effects remain unclear. It has been suggested that the acute psychoactive effects of subanaesthetic doses of ketamine may be associated with its therapeutic benefits, rather than being inconsequential or unwelcome side effects. We use the term 'acute psychoactive effects' to describe subjective symptoms, including dissociative, psychotomimetic and 'mystical' effects experienced during or shortly after ketamine administration. Determining whether these effects are related to treatment efficacy is crucial to optimize ketamine's therapeutic potential.

The acute psychoactive effect that has been most widely investigated in antidepressant ketamine studies is dissociation. Symptoms induced by dissociative drugs can range from feelings of detachment from oneself and one's environment, disorientation, confusion and changes in sensory perception to hallucinations and memory loss. In the context of therapeutic ketamine infusions, dissociation is usually mild to moderate and subsides shortly after drug administration. An increase in prefrontal extracellular glutamate during ketamine administration is considered to contribute to these transient effects (5). There is a sizeable body of research to support a 'glutamate hypothesis' of depression, whereby pathophysiology is associated with reduced prefrontal glutamate and clinical remission with normalising glutamate levels (6). Several studies have found a relationship between dissociative symptoms during ketamine administration and depression outcomes, which gave rise to the hypothesis that increases in dissociation during ketamine administration might be related to the therapeutic efficacy of ketamine via increased glutamate activity in the brain (7).

Similar to dissociative effects, sub-anaesthetic doses of ketamine can induce transient 'psychosislike'- symptoms including hallucinations, persecutory ideas, and altered cognition (8). These "psychotomimetic effects' have been investigated particularly in the context of ketamine as a 'model' for schizophrenia (9). The assessment of psychotomimetic effects is now common practice in studies administering sub-anaesthetic doses of ketamine. However, the literature on a potential relationship between ketamine induced psychotomimetic effects and treatment outcomes is less established than for dissociative effects. However, it is feasible that the psychotomimetic properties of ketamine are 
important for treatment outcomes partly due to their similarities with hallucinogenic drugs, as discussed below.

The importance of the immediate experience of a psychoactive drug on therapeutic outcomes received initial attention in the 1950s, when scientific investigation on therapeutic substances such as lysergic acid diethylamide (LSD) began (10). Fostering and integrating drug induced shifts in perspective has been an essential component of psychedelic therapy and has led to a specific focus on the context (i.e. set and setting) in which the drug is administered. Here "set" refers to the psychological context and "setting" to the environmental context in which the psychedelic drug experience occurs. The aim is to create a comfortable, non-judgemental environment and provide psychological support to aid the recovery of the patient. Recent studies found that measures of mystical experience during psilocybin administration were positively related to subsequent antidepressant response $(11,12)$, and smoking cessation success (13). Furthermore, these studies paid close attention to the idea of "set" and "setting": psychological guidance was given before, during and after the psychedelic experience and a low lit, 'living-room-like' space was provided.

Though ketamine, like psilocybin, has been described as giving rise to mystical experiences, few studies have investigated whether these experiences are positively related to subsequent psychiatric benefits. One recent study found that greater intensity of mystical experiences during ketamine was related to global improvement in dependent cocaine users (14). Interestingly no psychological guidance was given in this study.

Distinguishing the mechanisms by which ketamine exerts its therapeutic benefits is key to effective treatment implementation. Therefore, elucidating the relationship between acute ketamine experience and psychiatric outcomes would have several benefits. If acute psychoactive effects were found to predict clinical outcomes, they may be utilized as a precise, objective measure of the likelihood of treatment success, allowing clinicians to identify patients for whom ketamine treatment may be most beneficial. Furthermore, it would be important to establish whether this relationship is contingent on the provision of a supportive context (ie. set and setting) or whether these effects can also occur "spontaneously". This could inform the development of treatment protocols and training for clinical staff to enhance and support the integration of acute psychoactive effects.

Conversely, it may be that acute psychoactive effects are unrelated to treatment outcomes. This would strengthen the rationale for developing similar drugs without ketamine's hallucinogenic or dissociative effects, which some patients may find distressing. Initial research into the antidepressant efficacy of NMDA receptor antagonists without these side-effects have shown promising results pre clinically, though none have robustly replicated the antidepressant properties of ketamine in humans $(15,16)$. 
Despite the proposed link between acute psychoactive effects and mental health treatment outcomes, it is unclear whether any conclusions can be drawn from the extant literature. To our knowledge, no publication has yet systematically reviewed existing articles which report on this relationship in a wide range of mental health conditions. We therefore conducted a systematic review of the literature to investigate the relationship between acute psychoactive effects and treatment outcomes in psychiatric populations.

\section{Methods}

\subsection{Search strategy}

The literature was searched using the electronic databases Medline, Embase and PsychInfo up to June $11^{\text {th }} 2019$. No other sources were searched. Searches were limited to peer reviewed papers written in English and involving humans. We used the following general keywords for the search: ketamine, esketamine, arketamine, experienc*, dissoc*, mystic*, psychedel*, psycho*, effect*, react*, anxi*, respon*, hallucin*, CADSS, BPRS, HMS, altered states of consciousness, spiritual, mental, depress, mood, psychiatric, addict*, abus*, misus*, dependen*, substance, suicide*, schizo*, psycho*, trauma*, dement*.

Search results are presented in Figure 1. A.B., B.M. and M.G. reviewed the electronic titles and selected the full text articles to be included. A $10 \%$ check was conducted independently by A.B. and M.G. on records they had not reviewed previously, and agreement was $100 \%$.

\subsection{Selection criteria}

Studies were included to be reviewed if they met the following criteria: samples were comprised of participants of 18 years or older, studies reported on the administration of ketamine as a treatment for a mental health condition, participants had a clinical diagnosis of a mental health condition, the effect of ketamine treatment on a mental health outcome was reported, an aspect of an acute psychoactive effect (dissociation, psychotomimetic effects, mystical experience etc.) was assessed during treatment administration using a quantitative measure, and studies reported on the relationship between the acute experience and the mental health outcome.

Studies were excluded if their sample size was smaller than five, or if the measures of acute psychoactive effects assessed symptoms related to the primary diagnosis. For example, an assessment of suicidal ideation during ketamine administration in a sample of depressed patients was considered not to be distinguishable from the underlying diagnosis, and therefore not acceptable as an 'acute psychoactive effect'. 


\subsection{Data extraction}

The following information was coded for each of the studies: number of participants per study, number of participants included in the calculation of the relationship between acute experience and treatment outcome, main diagnosis of patients, gender distribution, mean age, study design, route of ketamine administration, dose and duration of ketamine administration, measure used to assess the main outcome, assessment time-points main outcome measure, measure used to assess acute psychoactive effects, assessment time-points acute psychoactive effects, any reference in study set-up to set and setting (eg. provisions of psychological guidance, provision of specific environment) and result of outcome and experience association.

If available, comorbidities, number of ketamine infusions, and source statistics were also extracted. If the primary diagnosis was depression, the following additional information was extracted: presence of treatment resistance, definition of treatment resistance and use of concomitant antidepressants.

Age and gender means were adjusted for study sample size. Standard deviations therefore could not be calculated.

Data extraction was carried out by M.G. and a $100 \%$ check was conducted by A.B. and B.M. Any discrepancies identified were resolved by mutual consent.

\subsection{Rationale for not conducting meta-analyses}

As source statistics sufficient for effect size calculations were not reported in most cases, a metaanalysis was not conducted. In addition, there was substantial heterogeneity of study designs and assessment tools used and the majority of studies included did not test an a priori hypothesis about associations between mental health outcomes and acute psychoactive effects, but simply carried out a post-hoc analysis.

\section{Results}

Following full text review 31 studies were identified for data extraction. At the point of data extraction, we found that several publications included overlapping or identical datasets (17-28). In order to avoid repeatedly reporting on the same sample in this review, we decided to only include those publications reporting on pooled datasets of the above studies and to treat those pooled samples as one $(29,30)$. We therefore also refrained from extracting information on differences found between studies within the pooled dataset. This left 21 studies, with an overall sample size of 891 for final review (Tables 1 and S1). Results have been summarized by diagnoses below. 


\subsection{Depression}

A total of 17 studies of patients with a primary diagnosis of depression (TRD [ $\mathrm{k}=14]$, non-TRD $[\mathrm{k}=3])$ were retained in the final sample. The aggregate sample size of patients with depression that contributed to our association of interest was 739 . The studies were relatively small with $40 \%$ of all studies having an overall participant number of 20 or less. The mean age of participants was 44 years, $54 \%$ of participants were female (Table 1 ).

3.1.1. Depression: Study Design. Seven studies reported on non-randomized, non-controlled trials of open-label infusions of ketamine (31-37). Six studies employed a crossover design: in four studies participants received one dose of ketamine and one dose of saline (38-41), in one case midazolam was administered as an active comparator (42) and one study employed a crossover design were patients received ketamine in both conditions adjunctively to oral naltrexone or placebo (43). In all but one of the crossover studies the order of conditions was counterbalanced (44). Two studies employed a between subjects design. In one study participants were randomized to receive one of five possible infusions: $0.1,0.2,0.5$ or $1 \mathrm{mg} / \mathrm{kg}$ ketamine or midazolam (45). In the other study, participants were randomized to receive an oral antidepressant adjunctive to either esketamine or placebo nasal spray (46). Two further studies pooled samples from several studies with mixed designs. One of these reports on two open label and one between-subjects study (29) and one reports on two cross-over and one open label study (30) (Table 1).

In fifteen studies ketamine was administered through intravenous (IV) infusions. The most commonly used dose and duration were $0.5 \mathrm{mg} / \mathrm{kg}$ over 40 minutes $(\mathrm{k}=10)$. One study administered ketamine through an IV injection over 1 minute $(47)$ and two study through nasal spray $(48,49)$ (Table S1).

The time points of treatment outcome assessment were varied. Five studies assessed outcome measures within the first 24 hours after administration (29, 47, 49-51). Six studies measured outcome between one day and one week after administration (30, 44, 52-55). Two studies assessed outcome between one and two weeks after administration $(56,57)$ and four studies had an outcome assessment point of more than two weeks $(48,58-60)$ (Table 1).

Acute psychoactive effects were usually assessed shortly before and within an hour after administration. Only two studies assessed acute psychoactive effects at 4 hours after administration $(58,60)$.

Most of the studies in depressed patients did not specify any preparation, guidance, or therapy adjunctive to ketamine administration, contrary to the psychedelic therapy framework. Two studies mentioned the presence of a psychiatrist throughout the ketamine administration visit $(47,56)$ and one study indicated that a portion of patients underwent cognitive behavioural therapy (55). 
3.1.2. Depression: Diagnoses and Co-morbidities. Twelve studies reported on patients with a primary diagnosis of major depressive disorder $(29,44,47-51,53-56,58)$. Four studies reported on patients with both unipolar and bipolar depression $(30,52,57,60)$. One study explicitly reported on depressed patients with suicidal ideation (59) and one included only patients with severe depression or suicidal ideation (60) (Table 1).

Most studies were comprised of patients with TRD $(\mathrm{k}=14)$. Interestingly, the definition of treatment resistance varied considerably between studies, with the requirement of non-response ranging from one up to four ineffective antidepressant trials. In some studies non-response was restricted to the current depressive episodes $(47,48,51,53,56,58,59)$. One study furthermore required two failed psychological treatments (51) (Table S1).

Four studies explicitly required participants to discontinue use of concomitant antidepressants, with a wash-out period, before participation $(29,30,44,48,50,52)$. In all other studies participants were generally allowed to continue to use stable doses of antidepressants, with the exception of specific drugs in some cases (Table S1). Three studies explicitly excluded patients with almost any comorbid mental health diagnosis $(49,54,56)$. Of those who did not exclude for and reported on current comorbidities, the following diagnoses were reported: six studies reported comorbid anxiety disorders $(44,47,51,52,58,59)$, two reported current alcohol use disorder $(51,58)$, one reported a case of obsessive compulsive personality disorder, a case of borderline personality disorder, and a case of combined personality disorder (58) and one reported bulimia (51).

3.1.3. Depression: Acute Psychoactive Effects and Treatment Outcome. Seven studies found a relationship between acute psychoactive effects and treatment outcome (30,50,51,54,58-60), though five of these also reported at least one other measure for which no association was found $(29,30,58$ 60 ). Nine studies did not find any association between treatment outcome and acute psychoactive effects $(29,44,47-49,52,53,55-57)$ (Table 1).

All studies reporting on dissociative symptoms during ketamine administration employed the Clinician Administered Dissociative States Scale (CADSS) (61). Four studies found that CADSS scores positively correlated with an improvement in treatment outcomes: three studies reported a positive association between CADSS score and antidepressant response $(50,51,60)$, and one reported a positive relationship between the CADSS depersonalization subscale and antidepressant response (30). Studies reporting a positive relationship between CADSS scores and antidepressant response varied in sample size ( $\mathrm{N}=21$ [Moaddel et al.], $\mathrm{N}=43$ [Phillips et al.], $\mathrm{N}=97$ [Zheng et al.] and $\mathrm{N}=126$ [Niciu et al., 2018]). However, it should be noted that the two larger studies only found the association under specific conditions: Zheng, Zhou (60) found the positive relationship between CADSS and antidepressant outcome for one out of 6 infusions and Niciu, Shovestul (30) for a 
subscale of the CADSS. Only one study found a decline in mental health related to increased CADSS scores: here, a correlation of higher CADSS scores with higher suicidal ideation measured by the suicidal ideation subscale of the Hamilton Depression Rating Scale (HDRS) (62) was found (59). This study had a sample size of fourteen. Nine studies reported no significant association between antidepressant response and CADSS score $(29,44,48,49,53,55-57,63)$. Interestingly the study that reported a positive association between CADSS score and the HDRS suicidal ideation subscale (64), did not find a significant correlation with the suicidal ideation subscale of the Columbia Suicide Severity Rating Scale (C-SSRS) (65) and CADSS score (59). The studies that reported no relationship between CADSS and psychiatric outcome varied in sample size: four studies included twenty participants or less $(44,49,56,57)$, one had a sample size of 44 participants (57) and three had a sample size of 80 or more $(29,48,53)$ (Table 1$)$.

Five studies reported on psychotomimetic effects using the clinician administered Brief Psychiatric Rating Scale (BPRS) positive subscale (66), and two using the BPRS total. No study found a relationship was found between BPRS positive symptoms and anti-depressive response $(29,47,49$, $52,60)$. Two of these studies had 20 participants or less $(47,49)$, and two had over 80 participants $(29,60)$. One study, with a sample size of 27 , found a significant negative relationship between BPRS total score and antidepressant response (54). Generally, a correlation between BPRS total and antidepressant effects should be interpreted carefully as this scale includes items assessing depressive symptoms and therefore associations may be driven by the acute antidepressant effects of ketamine. None of the studies looked at BPRS negative symptoms (Table 1).

Two studies reported on mystical effects using the self-rated 5-Dimensional Altered States of Consciousness Rating Scale (5D-ASC) (67). One study found that an increase on the anxious ego disintegration subscale was negatively correlated with antidepressant efficacy (58). In this study no further association between 5D-ASC total or any of the other subscales was found. This study had a sample size of 31 . The other study did not find a relationship between 5D-ASC total and antidepressant response (47). This study had a sample size of 10 .

3.1.4. Depression: Statistical Reporting. Ten studies used a simple correlation to assess the relationship between the outcome measure and the acute psychoactive effect measure $(44,47,49,51$ $54,56,57,59)$. Two studies used regression analyses where either the relationship between outcome and acute psychoactive effect were assessed (30), or the acute psychoactive effects measure was included as a co-variate (55). Five studies defined responders and non-responders according to their outcome measures and then compared these groups on psychoactive effects $(29,48,50,58,60)$ (Table S1). 
There were marked differences in the statistics reported for each study. Of the 31 relationships assessed across the 17 depression studies, 12 reported a p-value and a regression or correlation coefficient $(29,47,51-54,56,59)$, six p-thresholds $(49,50,58)$, two p-values (59) and five no source statistics, but only text descriptions $(44,47,55,57)$ (Table S1).

\subsection{Substance use disorder}

We included three studies of ketamine as a treatment for a substance use disorder. Two studies were in patients with cocaine dependence and one study in patients with problematic alcohol use. A total of 134 participants contributed to the association of interest (see Table 1). The overall mean age of participants was 39 years, with $7 \%$ female participants.

3.2.1. Substance Use Disorder: Study Design. Both studies in cocaine dependent patients were randomised, active placebo-controlled crossover trials of IV infusions of ketamine. Dakwar et al (2014) included 8 participants, Dakwar et al. (2018) included 18 participants. Participants received either midazolam (68) or lorazepam (69) as an active control. Dakwar et al. (2014) administered a low and a high dose of ketamine, however, only the lower dose $(0.41 \mathrm{mg} / \mathrm{kg})$ contributed to the analysis of interest. The study in patients with problematic alcohol use was an open label trial in 108 participants. They received a dose of $2.5 \mathrm{mg} / \mathrm{kg}$ by intramuscular injection, together with premedication given to enhance the ketamine-induced experiences (70).

Both cocaine studies measured dissociation and mystical experiences, using the CADSS and the selfreported Hood's Mysticism Scale (HMS) respectively (Hood Jr, 1975). Dakwar, Nunes (68) measured Near Death Experiences (NDE) using the self-reported Near-Death Experiences Scale (NDES) (Greyson and Dis, 1983). Dakwar et al (2014) administered their scales within 15 minutes of the infusion finishing; Dakwar et al (2018) within 20 minutes. The alcohol study measured the intensity of patient self-reported negative experiences during ketamine administration on a 0 (no negative experiences) to 3 (severe negative experiences) scale (Krupitsky \& Grinenko, 1997). Negative experiences were defined as those associated with fear, horror, anxiety and other negative emotions. Patients completed their self-report retrospectively on the evening after ketamine administration.

All three studies made reference to some aspects of psychedelic therapy. Both studies in cocaine dependent patients did not include psychological therapy but provided a short mindfulness training before the ketamine infusion. Krupitsky and Grinenko (71) developed a protocol of a psychotherapeutic ketamine intervention conducted before, during and after the ketamine infusion. This included specific set and setting considerations, including music played in the background and therapeutic guidance during the ketamine administration. 
3.2.2. Substance Use Disorder: Diagnoses and Co-morbidities. Two studies included participants who were non-treatment seeking individuals with cocaine dependence with no history of depressive, psychotic, dissociative or anxiety symptoms (DSM-IV SCID) $(68,72)$. One of these studies included participants with a history of post-traumatic stress disorder (PTSD) and comorbid alcohol use disorder (68). One study focused on patients with alcohol dependence; co-morbidities were not reported (71).

\subsubsection{Substance Use Disorder: Relationship Between Acute Psychoactive Effects and Outcome.}

All three studies found a relationship between treatment outcome and acute psychoactive effects. Both cocaine studies found HMS score to mediate outcome. One found HMS score to mediate motivation to quit cocaine, but not on cue-induced craving $(\mathrm{N}=8)(72)$. The other study found HMS score to mediate improvements in the composite improvement score $(\mathrm{N}=18)$ (68). Importantly, both cocaine studies noted initial correlation between CADSS and therapeutic outcome, but this was not significant in the mediation analysis. Dakwar, Nunes (68) also noted an initial correlation between NDES and composite improvement score, which was not significant in the mediation analysis. In the alcohol study, increased ketamine induced negative experiences correlated positively with length of remission from alcohol use $(\mathrm{N}=108)(\mathrm{REF})$.

Two studies reported correlation and regression coefficients and p-values $(68,72)$ and one a correlation coefficient and a p-thresholds (71).

\subsection{Anxiety}

One study investigated ketamine as a treatment for anxiety, specifically Social Anxiety Disorder (SAD) (73). Among a sample size of 18 , with a mean age of 29.7, seven participants were female.

3.3.1. Anxiety: Study Design. This was a placebo-controlled, double-blind, crossover trial in which participants were administered one infusion of ketamine $(0.5 \mathrm{mg} / \mathrm{kg}$, for 40 minute IV infusion) and one of saline, in a random order, with a 28 day interval between infusions. The primary outcome measures of interest were a VAS of self-reported anxiety, and the clinician rated Liebowitz Social Anxiety Scale (LSAS). Outcome assessments were conducted at multiple time points up to 14 days post each infusion. Acute psychoactive effects were assessed via the CADSS.

No preparation, guidance, or therapy adjunctive to ketamine administration was reported in this study.

3.3.2. Anxiety: Diagnoses and Co-morbidities. The authors detail a high level of comorbid mood and anxiety disorders within the sample. The following disorders were reported as currently comorbid for between one and five of the study participants: generalised anxiety disorder, specific phobia, major depressive disorder, persistent depressive disorder and panic disorder. Stable psychiatric 
medications were permitted during the study, though anxiolytic medications prescribed 'as needed' were discontinued for the trial. Additionally, patients were not permitted to be receiving concurrent cognitive behavioural therapy.

\subsubsection{Anxiety: Relationship Between Acute Psychoactive Effects and Outcome. Maximum}

CADSS rating following ketamine infusion did not significantly moderate the effects of ketamine on either VAS or LSAS scores. Thus, no association between dissociative experiences during ketamine administration and anxiety was observed in this study.

The study reported the $\mathrm{F}$ value of the regression and a $\mathrm{p}$-value.

\section{Discussion}

This review demonstrates that the current literature investigating the association between ketamine's acute psychoactive effects and psychiatric treatment outcomes is inconclusive. The majority of reviewed studies assessed ketamine as a treatment for TRD depression $(\mathrm{k}=17)$. Of all 33 relationships assessed across the depression studies, $20 \%$ were significant. Three studies assessed ketamine as a treatment for substance dependence, specifically cocaine $(\mathrm{k}=2)$ and alcohol use $(\mathrm{k}=1)$. All 6 relationships assessed across the substance dependence studies were significant. One study assessed ketamine as a treatment for social anxiety disorder. The two relationships that were assessed in this study were not significant.

The majority of studies reviewed used either a crossover or open-label design in which ketamine was administered intravenously. The reporting of source statistics assessing the relationship of interest was generally sparse, we found that $30 \%$ of relationships assessed were merely characterised by p-values or thresholds or described in text without the provision of statistics. Studies varied in terms of outcome assessment timepoints, drug administration protocols, and exclusion/inclusion criteria for participants. Consequently, study designs and methodologies used were too heterogeneous to permit meaningful meta-analysis.

A range of psychoactive effects were assessed: 76\% (16/21) of studies measured dissociation, 24\% $(5 / 21)$ of studies measured psychotomimetic effects and 18\% (4/22) measured mystical experiences.

Dissociative symptoms did not consistently correlate with treatment outcomes. Dissociation was mainly assessed in depressed patients using the CADSS. The CADSS is the most commonly used measure of dissociation and is well validated for use in disorders that give rise to dissociative symptoms, such as post-traumatic stress disorder (74). The ability of the CADSS to fully capture drug induced dissociation, however, is currently unclear. Whilst van Schalkwyk et al. (75) reported acceptable internal consistency of the CADSS (Chronbach's alpha $=0.74)$ and suggested that it may 
only partially describe acute dissociative symptomatology during ketamine administration, Neehoff and Glue (76) contrasted this with findings from a study in which all CADSS items were responsive to drug induced dissociation and higher internal consistency (Chronbach's alpha $=0.94)(77)$. As the studies differed in dose of ketamine assessed as well as patient group, further research is warranted to assess the source for these discrepancies.

Three studies in depressed patients found a positive relationship between CADSS total and antidepressant response $(50,51,60)$, one between the 'depersonalization' subscale and antidepressant response (30) and one found a negative relationship between CADSS total and relief from suicidal ideation (59). Nine studies found no relationship (29, 44, 48, 49, 53, 55-57, 63). Two studies found a correlation between CADSS total and global improvement in cocaine dependence $(68,72)$. The study assessing social anxiety did not find a relationship between CADSS total and anxiolytic response (78). Overall, of those studies that found a relationship, $86 \%$ reported a positive association between CADSS and treatment efficacy. This could indicate that stronger dissociation fosters a positive therapeutic outcome under some conditions. However, the high amount of studies failing to find a relationship suggests that high measures on the CADSS during ketamine administration are not necessary for the therapeutic efficacy of ketamine under all circumstances. Notably, only three studies stated an a-priori hypothesis regarding the relationship between CADSS and treatment outcome, all of which were secondary analyses $(30,68,72)$.

The BPRS is the most widely used scale to assess psychotic symptoms and is well validated (79). The psychotomimetic effects of ketamine have been thoroughly documented, as it has been suggested to, at least in part, act as a model for schizophrenia (80). Thus, the BPRS, or its positive effects subscale, appears to provide an adequate measure of the psychotomimetic effects of ketamine. However, the PSI (Psychotomimetic State Inventory) was designed to assess psychotomimetic effects to drugs specifically, therefore its use alongside the BPRS may be warranted (81).

Psychotomimetic effects were exclusively assessed in depressed patients using either the BPRS total or the BPRS positive effects subscale. None of the studies that assessed BPRS positive symptoms found a relationship with treatment outcome $(29,47,49,52,60)$. One studies reported a negative correlation between BPRS total and antidepressant response (54). This study stated an a priori hypothesis regarding psychotomimetic effects and treatment outcome (54). Overall, there is currently insufficient evidence to support an association between BPRS positive scores and antidepressant response. Available research on the relationship between the BPRS total and antidepressant response is scarce and may be confounded by the fact that the BPRS total includes items on depressive symptoms. 
Only a small number of studies assessed mystical experiences during ketamine administration, therefore this acute effect is likely not adequately captured by existing research. The importance of investigating mystical experiences during ketamine administration is backed by descriptions of ketamine experiences suggesting that patients do in fact experience acute psychoactive effects that fit into "mystical-type" experiences $(71,82)$.

Two studies in cocaine dependent patients used the HMS to assess mystical experiences, and two studies in depressed patients used the 5D-ASC rating scale. Both studies using the HMS found that mystical effects mediated the effect of ketamine on global improvement in cocaine dependence (68, 72). Notably, both stated an a priori hypothesis that mystical effects would mediate the effect of ketamine on treatment outcome, whereas CADSS would only correlate with, but not mediate, treatment outcome. The two studies in depressed patients reported mixed results. One found a negative relationship between increases on the anxiety subscale of the 5D-ASC and relief from depression (58) and one found no relationship (47). Aust et al. (58) stated a general a priori hypothesis that responders and non-responders would differ on their subjective experiences of ketamine.

Overall, this review demonstrates that a broad range of acute psychoactive effects of ketamine have been assessed in the literature, but to varying degrees. It should be noted that the primary reason for employment of the CADSS and the BPRS in therapeutic ketamine studies is to assess the acute tolerability of ketamine rather than to comprehensively capture ketamine's psychoactive effects. Moreover, preliminary hypotheses on the relationship between these measures and treatment outcome are rare. Thus, the fact that these are the most thoroughly investigated measures is likely due to reasons other than their potential to predictive treatment efficacy. Furthermore, as measures of mystical experiences were in the minority it is not currently feasible to draw firm conclusions on whether they might predict treatment efficacy.

Based on the literature reviewed we can conclude that further research into the association between acute psychoactive effect and therapeutic treatment outcomes is needed. In order to appropriately assess this relationship, and its potential underlying mechanisms, a number of recommendations are made:

First, studies should be sufficiently powered to assess this relationship and specific a priori hypotheses given in pre-registered protocols published prior to data collection. Second, greater emphasis should be given to replicating earlier findings, and the development of standardized studyprotocols regarding assessment time-points, dosing, clinician versus self-rating of scales, patient characteristics etc. Third, statistics should be reported more consistently and thoroughly, including measures of effect size, spread and skew. Fourth, adequate measures should be used to 
comprehensively capture ketamine's acute psychoactive effects, for example using the PSI to assess psychotomimetic effects and developing new assessment tools in the future. Fifth, most of the reviewed studies did not describe the concepts of "set" and "setting" as part of the study set up. Only three studies made explicit reference to set and setting $(68,71,72)$, and only one gave psychological guidance before, during and after ketamine administration (71). Interestingly, all three studies were in substance dependent patients and found a positive relationship between acute psychoactive effects and treatment outcome. Given the scarcity of studies and some initial promising findings it would be advisable to investigate the role of "set" and "setting" in future research.

Another finding of this review was the high level of variability between studies in the characterisation of treatment resistance in depressed patients. Studies varied in terms of their minimum requirement of ineffective antidepressant trials (ranging from 1-4), whether these had to have been prescribed during the current episode, whether they had to have been from different drug classes, and whether treatment with non-pharmacological methods must have been attempted. This finding is important in light of the recent approval of Esketamine for use in TRD by both the FDA and the EMA. Future decisions on the specific patient group that Esketamine should be made available for must take into account that the definition of treatment resistance in the scientific literature is not standardized.

The present review has a number of limitations: First, most of the included studies reported no $a$ priori hypotheses on the relationship between ketamine's acute psychoactive effects and psychiatric outcomes. Therefore, the risk of underreporting is high. Second, a meta-analysis of the included studies, which may have served to resolve some of the uncertainty in the presented literature, could not be conducted as a result of methodological variability. Third, as a result of resource and time constraints, there was little scope for clarifying study details with the original authors. This is especially relevant given the limited reporting of source statistics of many of the studies included in the review. The current authors were therefore unable to include in the review the large number of published studies which measure both acute psychoactive effect during ketamine administration and mental health treatment outcomes but did not report on their correlation.

In conclusion, we found that the current evidence regarding the presence as well as the direction of the relationship between ketamine's acute psychoactive effects and treatment outcomes in various mental health conditions is equivocal. Much of the uncertainty regarding this relationship could be clarified if future research addressed some of the methodological issues present in much of the current literature. 
Acute Ketamine Experience and Psychiatric Outcomes

\section{Funding Sources}

C.M., M.G. and B.M. are funded by a Medical Research Council grant (NCT02649231) A.B. is currently funded by a one year fellowship via UCL NIHR BRC. HVC's research is funded by the UK Medical Research Council and UCL NIHR BRC. 


\section{References}

1. Glue P, Medlicott NJ, Harland S, Neehoff S, Anderson-Fahey B, Le Nedelec M, et al.

Ketamine's dose-related effects on anxiety symptoms in patients with treatment refractory anxiety disorders. Journal of Psychopharmacology. 2017;31(10):1302-5.

2. Rodriguez CI, Kegeles LS, Levinson A, Feng T, Marcus SM, Vermes D, et al. Randomized controlled crossover trial of ketamine in obsessive-compulsive disorder: proof-of-concept.

Neuropsychopharmacology. 2013;38(12):2475-83.

3. Jones JL, Mateus CF, Malcolm RJ, Brady KT, Back SE. Efficacy of ketamine in the treatment of substance use disorders: a systematic review. Frontiers in Psychiatry. 2018;9.

4. Ezquerra-Romano II, Lawn W, Krupitsky E, Morgan CJN. Ketamine for the treatment of addiction: Evidence and potential mechanisms. Journal of Neuropharmacology. 2018;142:72-82.

5. Zorumski CF, Izumi Y, Mennerick S. Ketamine: NMDA Receptors and Beyond. Journal of Neuroscience. 2016;36(44):11158-64.

6. Sanacora G, Treccani G, Popoli M. Towards a glutamate hypothesis of depression: an emerging frontier of neuropsychopharmacology for mood disorders. Neuropharmacology. 2012;62(1):63-77.

7. Luckenbaugh DA, Niciu MJ, Ionescu DF, Nolan NM, Richards EM, Brutsche NE, et al. Do the dissociative side effects of ketamine mediate its antidepressant effects? Journal of Affective Disorders. 2014;159:56-61.

8. Krystal JH, Karper LP, Seibyl JP, Freeman GK, Delaney R, Bremner JD, et al. Subanesthetic effects of the noncompetitive NMDA antagonist, ketamine, in humans. Psychotomimetic, perceptual, cognitive, and neuroendocrine responses. Archives of General Psychiatry. 1994;51(3):199-214.

9. Frohlich J, Van Horn JD. Reviewing the ketamine model for schizophrenia. Journal of Psychopharmacology. 2014;28(4):287-302.

10. Leary T, Litwin GH, Metzner R. Reactions to Psilocybin Administered in a Supportive Environment. Journal of Nervous and Mental Disease. 1963;137:561-73.

11. Griffiths RR, Johnson MW, Carducci MA, Umbricht A, Richards WA, Richards BD, et al. Psilocybin produces substantial and sustained decreases in depression and anxiety in patients with life-threatening cancer: A randomized double-blind trial. Journal of Psychopharmacology. 2016;30(12):1181-97.

12. Roseman L, Nutt DJ, Carhart-Harris RL. Quality of Acute Psychedelic Experience Predicts Therapeutic Efficacy of Psilocybin for Treatment-Resistant Depression. Frontiers in Pharmacology. 2017;8:974.

13. Garcia-Romeu A, Griffiths RR, Johnson MW. Psilocybin-occasioned mystical experiences in the treatment of tobacco addiction. Current Drug Abuse Reviews. 2014;7(3):157-64. 
14. Dakwar E, Nunes E, Hart C, Hu M, Foltin R, Levin FJN. A sub-set of psychoactive effects may be critical to the behavioral impact of ketamine on cocaine use disorder: Results from a randomized, controlled laboratory study. Journal of Neuropharmacology. 2018;142:270-6.

15. Li N, Lee B, Liu RJ, Banasr M, Dwyer JM, Iwata M, et al. mTOR-dependent synapse formation underlies the rapid antidepressant effects of NMDA antagonists. Science. 2010;329(5994):959-64.

16. Ibrahim L, Diaz Granados N, Jolkovsky L, Brutsche N, Luckenbaugh DA, Herring WJ, et al. A Randomized, placebo-controlled, crossover pilot trial of the oral selective NR2B antagonist MK0657 in patients with treatment-resistant major depressive disorder. Journal of Clinical Psychopharmacology. 2012;32(4):551-7.

17. Wan LB, Levitch CF, Perez AM, Brallier JW, Iosifescu DV, Chang LC, et al. Ketamine safety and tolerability in clinical trials for treatment-resistant depression. Journal of Clinical Psychiatry. 2015;76(3):247-52.

18. Murrough JW, Perez AM, Pillemer S, Stern J, Parides MK, aan het Rot M, et al. Rapid and longer-term antidepressant effects of repeated ketamine infusions in treatment-resistant major depression. Biological Psychiatry. 2013;74(4):250-6.

19. Murrough JW, Wan L-B, Iacoviello B, Collins KA, Solon C, Glicksberg B, et al. Neurocognitive effects of ketamine in treatment-resistant major depression: association with antidepressant response. Journal of Psychopharmacology. 2014;231(3):481-8.

20. Mathew SJ, Murrough JW, an het Rot M, Collins KA, Reich DL, Charney DS. Riluzole for relapse prevention following intravenous ketamine in treatment-resistant depression: a pilot randomized, placebo-controlled continuation trial. International Journal of Neuropsychopharmacology. 2010;13(1):71-82.

21. Price RB, Iosifescu DV, Murrough JW, Chang LC, Al Jurdi RK, Iqbal SZ, et al. Effects of ketamine on explicit and implicit suicidal cognition: a randomized controlled trial in treatmentresistant depression. Depression and Anxiety. 2014;31(4):335-43.

22. Niciu MJ, Shovestul BJ, Jaso BA, Farmer C, Luckenbaugh DA, Brutsche NE, et al. Features of dissociation differentially predict antidepressant response to ketamine in treatment-resistant depression. Journal of Affective Disorders. 2018;232:310-5.

23. Pennybaker SJ, Niciu MJ, Luckenbaugh DA, Zarate CA. Symptomatology and predictors of antidepressant efficacy in extended responders to a single ketamine infusion. Journal of Affective Disorders. 2017;208:560-6.

24. Luckenbaugh DA, Niciu MJ, Ionescu DF, Nolan NM, Richards EM, Brutsche NE, et al. Do the dissociative side effects of ketamine mediate its antidepressant effects? 2014;159:56-61.

25. Duncan Jr WC, Sarasso S, Ferrarelli F, Selter J, Riedner BA, Hejazi NS, et al. Concomitant BDNF and sleep slow wave changes indicate ketamine-induced plasticity in major depressive disorder. International Journal of Neuropsychopharmacology. 2012;16(2):301-11. 
26. Diazgranados N, Ibrahim L, Brutsche NE, Newberg A, Kronstein P, Khalife S, et al. A randomized add-on trial of an N-methyl-D-aspartate antagonist in treatment-resistant bipolar depression. Archives of General Psychiatry. 2010;67(8):793-802.

27. Zarate CA, Jr., Singh JB, Carlson PJ, Brutsche NE, Ameli R, Luckenbaugh DA, et al. A randomized trial of an $\mathrm{N}$-methyl-D-aspartate antagonist in treatment-resistant major depression. Archives of General Psychiatry. 2006;63(8):856-64.

28. Carlson PJ, Diazgranados N, Nugent AC, Ibrahim L, Luckenbaugh DA, Brutsche N, et al. Neural correlates of rapid antidepressant response to ketamine in treatment-resistant unipolar depression: a preliminary positron emission tomography study. Biological Psychiatry. 2013;73(12):1213-21.

29. Wan L-B, Levitch CF, Perez AM, Brallier JW, Iosifescu DV, Chang LC, et al. Ketamine safety and tolerability in clinical trials for treatment-resistant depression. 2015;76(3):247-52. 30. Niciu MJ, Shovestul BJ, Jaso BA, Farmer C, Luckenbaugh DA, Brutsche NE, et al. Features of dissociation differentially predict antidepressant response to ketamine in treatment-resistant depression. 2018;232:310-5.

31. Aust S, Gärtner M, Basso L, Otte C, Wingenfeld K, Chae WR, et al. Anxiety during ketamine infusions is associated with negative treatment responses in major depressive disorder. Journal of European Neuropsychopharmacology. 2019;29(4):529-38.

32. Ionescu DF, Swee MB, Pavone KJ, Taylor N, Akeju O, Baer L, et al. Rapid and Sustained Reductions in Current Suicidal Ideation Following Repeated Doses of Intravenous Ketamine: Secondary Analysis of an Open-Label Study. Journal of Clinical Psychiatry. 2016;77(6):e719-25. 33. Moaddel R, Luckenbaugh DA, Xie Y, Villaseñor A, Brutsche NE, Machado-Vieira R, et al. $\mathrm{D}$-serine plasma concentration is a potential biomarker of $(\mathrm{R}, \mathrm{S})$-ketamine antidepressant response in subjects with treatment-resistant depression. Journal of Psychopharmacology. 2015;232(2):399-409. 34. Shiroma PR, Johns B, Kuskowski M, Wels J, Thuras P, Albott CS, et al. Augmentation of response and remission to serial intravenous subanesthetic ketamine in treatment resistant depression. Journal of Affective Disorders. 2014;155:123-9.

35. Vidal S, Gex-Fabry M, Bancila V, Michalopoulos G, Warrot D, Jermann F, et al. Efficacy and Safety of a Rapid Intravenous Injection of Ketamine $0.5 \mathrm{mg} / \mathrm{kg}$ in Treatment-Resistant Major Depression: An Open 4-Week Longitudinal Study. Journal of Clinical Psychopharmacology. 2018;38(6):590-7.

36. Wilkinson ST, Katz RB, Toprak M, Webler R, Ostroff RB, Sanacora GJTJocp. Acute and Longer-Term Outcomes Using Ketamine as a Clinical Treatment at the Yale Psychiatric Hospital. Journal of Clinical Psychiatry. 2018;79(4).

37. Zheng W, Zhou YL, Liu WJ, Wang CY, Zhan YN, Li HQ, et al. Rapid and longer-term antidepressant effects of repeated-dose intravenous ketamine for patients with unipolar and bipolar depression. Journal of Psychiatric Research. 2018;106:61-8. 
38. Berman RM, Cappiello A, Anand A, Oren DA, Heninger GR, Charney DS, et al. Antidepressant effects of ketamine in depressed patients. Biological Psychiatry. 2000;47(4):351-4.

39. Sos P, Klirova M, Novak T, Kohutova B, Horacek J, Palenicek T. Relationship of ketamine's antidepressant and psychotomimetic effects in unipolar depression. Neuroendocrinology Letters. 2013;34(4):287-93.

40. Valentine GW, Mason GF, Gomez R, Fasula M, Watzl J, Pittman B, et al. The antidepressant effect of ketamine is not associated with changes in occipital amino acid neurotransmitter content as measured by [1H]-MRS. Psychiatry Research: Neuroimaging. 2011;191(2):122-7.

41. Lapidus KA, Levitch CF, Perez AM, Brallier JW, Parides MK, Soleimani L, et al. A randomized controlled trial of intranasal ketamine in major depressive disorder. Biological Psychiatry. 2014;76(12):970-6.

42. Phillips JL, Norris S, Talbot J, Birmingham M, Hatchard T, Ortiz A, et al. Single, Repeated, and Maintenance Ketamine Infusions for Treatment-Resistant Depression: A Randomized Controlled Trial. American Journal of Psychiatry. 2019;176(5):401-9.

43. Williams NR, Heifets BD, Blasey C, Sudheimer K, Pannu J, Pankow H, et al. Attenuation of Antidepressant Effects of Ketamine by Opioid Receptor Antagonism. American Journal of Psychiatry. 2018;175(12):1205-15.

44. Valentine GW, Mason GF, Gomez R, Fasula M, Watzl J, Pittman B, et al. The antidepressant effect of ketamine is not associated with changes in occipital amino acid neurotransmitter content as measured by [1H]-MRS. 2011;191(2):122-7.

45. Fava M, Freeman MP, Flynn M, Judge H, Hoeppner BB, Cusin C, et al. Double-blind, placebo-controlled, dose-ranging trial of intravenous ketamine as adjunctive therapy in treatmentresistant depression (TRD). Journal of Molecular Psychiatry. 2018:1.

46. Popova V, Daly EJ, Trivedi M, Cooper K, Lane R, Lim P, et al. Efficacy and Safety of Flexibly Dosed Esketamine Nasal Spray Combined With a Newly Initiated Oral Antidepressant in Treatment-Resistant Depression: A Randomized Double-Blind Active-Controlled Study. American Journal of Psychiatry. 2019;176(6):428-38.

47. Vidal S, Gex-Fabry M, Bancila V, Michalopoulos G, Warrot D, Jermann F, et al. Efficacy and safety of a rapid intravenous injection of ketamine $0.5 \mathrm{mg} / \mathrm{kg}$ in treatment-resistant major depression: An open 4-week longitudinal study. 2018;38(6):590-7.

48. Popova V, Daly EJ, Trivedi M, Cooper K, Lane R, Lim P, et al. Efficacy and safety of flexibly dosed esketamine nasal spray combined with a newly initiated oral antidepressant in treatment-resistant depression: a randomized double-blind active-controlled study. 2019;176(6):42838.

49. Lapidus KA, Levitch CF, Perez AM, Brallier JW, Parides MK, Soleimani L, et al. A randomized controlled trial of intranasal ketamine in major depressive disorder. 2014;76(12):970-6. 
50. Moaddel R, Luckenbaugh DA, Xie Y, Villaseñor A, Brutsche NE, Machado-Vieira R, et al. D-serine plasma concentration is a potential biomarker of $(\mathrm{R}, \mathrm{S})$-ketamine antidepressant response in subjects with treatment-resistant depression. 2015;232(2):399-409.

51. Phillips JL, Norris S, Talbot J, Birmingham M, Hatchard T, Ortiz A, et al. Single, repeated, and maintenance ketamine Infusions for treatment-resistant depression: a randomized controlled trial. 2019;176(5):401-9.

52. Berman RM, Cappiello A, Anand A, Oren DA, Heninger GR, Charney DS, et al. Antidepressant effects of ketamine in depressed patients. 2000;47(4):351-4.

53. Fava M, Freeman MP, Flynn M, Judge H, Hoeppner BB, Cusin C, et al. Double-blind, placebo-controlled, dose-ranging trial of intravenous ketamine as adjunctive therapy in treatmentresistant depression (TRD). 2018:1.

54. Sos P, Klirova M, Novak T, Kohutova B, Horacek J, Palenicek TJNL. Relationship of ketamine's antidepressant and psychotomimetic effects in unipolar depression. 2013;34(4):287-93. 55. Wilkinson ST, Katz RB, Toprak M, Webler R, Ostroff RB, Sanacora GJTJocp. Acute and Longer-Term Outcomes Using Ketamine as a Clinical Treatment at the Yale Psychiatric Hospital. 2018;79(4).

56. Shiroma PR, Johns B, Kuskowski M, Wels J, Thuras P, Albott CS, et al. Augmentation of response and remission to serial intravenous subanesthetic ketamine in treatment resistant depression. 2014;155:123-9.

57. Williams NR, Heifets BD, Blasey C, Sudheimer K, Pannu J, Pankow H, et al. Attenuation of antidepressant effects of ketamine by opioid receptor antagonism. 2018;175(12):1205-15.

58. Aust S, Gärtner M, Basso L, Otte C, Wingenfeld K, Chae WR, et al. Anxiety during ketamine infusions is associated with negative treatment responses in major depressive disorder. 2019;29(4):529-38.

59. Ionescu DF, Swee MB, Pavone KJ, Taylor N, Akeju O, Baer L, et al. Rapid and sustained reductions in current suicidal ideation following repeated doses of intravenous ketamine. 2016;77(6):e719-e25.

60. Zheng W, Zhou Y-L, Liu W-J, Wang C-Y, Zhan Y-N, Li H-Q, et al. Rapid and longer-term antidepressant effects of repeated-dose intravenous ketamine for patients with unipolar and bipolar depression. 2018;106:61-8.

61. Bremner JD, Krystal JH, Putnam FW, Southwick SM, Marmar C, Charney DS, et al. Measurement of dissociative states with the Clinician-Administered Dissociative States Scale (CADSS). Journal of Traumatic Stress. 1998;11(1):125-36.

62. Hamilton M. A rating scale for depression. Journal of neurology, neurosurgery, and psychiatry. 1960;23(1):56-62. 
63. Carlson PJ, Diazgranados N, Nugent AC, Ibrahim L, Luckenbaugh DA, Brutsche N, et al. Neural correlates of rapid antidepressant response to ketamine in treatment-resistant unipolar depression: a preliminary positron emission tomography study. 2013;73(12):1213-21.

64. Hamilton M. A rating scale for depression. 1960;23(1):56.

65. Posner K, Brent D, Lucas C, Gould M, Stanley B, Brown G, et al. Columbia-suicide severity rating scale (C-SSRS). 2008.

66. Overall JE, Gorham DRJPr. The brief psychiatric rating scale. Psychological Reports. 1962;10(3):799-812.

67. Dittrich A, Lamparter D, Maurer MJEkEPP, Zürich. 5D-ABZ: Fragebogen zur Erfassung Aussergewöhnlicher Bewusstseinszustände. 1999.

68. Dakwar E, Nunes E, Hart C, Hu M, Foltin R, Levin FJN. A sub-set of psychoactive effects may be critical to the behavioral impact of ketamine on cocaine use disorder: Results from a randomized, controlled laboratory study. 2018;142:270-6.

69. Dakwar E, Anerella C, Hart C, Levin F, Mathew S, Nunes EJD, et al. Therapeutic infusions of ketamine: do the psychoactive effects matter? Journal of Drug and Alcohol Dependence. 2014;136:153-7.

70. Krupitsky EM, Grinenko AY. Ketamine psychedelic therapy (KPT): a review of the results of ten years of research. Journal of Psychoactive Drugs. 1997;29(2):165-83.

71. Krupitsky E, Grinenko AJJopd. Ketamine psychedelic therapy (KPT): a review of the results of ten years of research. 1997;29(2):165-83.

72. Dakwar E, Anerella C, Hart C, Levin F, Mathew S, Nunes EJD, et al. Therapeutic infusions of ketamine: do the psychoactive effects matter? 2014;136:153-7.

73. Taylor JH, Landeros-Weisenberger A, Coughlin C, Mulqueen J, Johnson JA, Gabriel D, et al. Ketamine for Social Anxiety Disorder: A Randomized, Placebo-Controlled Crossover Trial. Neuropsychopharmacology. 2018;43(2):325-33.

74. Bremner JD, Krystal JH, Putnam FW, Southwick SM, Marmar C, Charney DS, et al. Measurement of dissociative states with the clinician-administered dissociative states scale (CADSS). 1998;11(1):125-36.

75. van Schalkwyk GI, Wilkinson ST, Davidson L, Silverman WK, Sanacora G. Acute psychoactive effects of intravenous ketamine during treatment of mood disorders: Analysis of the Clinician Administered Dissociative State Scale. Journal of Affective Disorders. 2018;227:11-6.

76. Neehoff S, Glue PJJoad. Dissociation after ketamine dosing: Is the CADSS fit for purpose? Journal of Affective Disorders. 2019;244:239-40.

77. Castle C, Gray A, Neehoff S, Glue P. Effect of ketamine dose on self-rated dissociation in patients with treatment refractory anxiety disorders. Journal of Psychopharmacology.

2017;31(10):1306-11. 
78. Taylor JH, Landeros-Weisenberger A, Coughlin C, Mulqueen J, Johnson JA, Gabriel D, et al. Ketamine for social anxiety disorder: A randomized, placebo-controlled crossover trial.

2018;43(2):325.

79. Overall JE, Gorham DRJPr. The brief psychiatric rating scale. 1962;10(3):799-812.

80. Frohlich J, Van Horn JDJJop. Reviewing the ketamine model for schizophrenia. 2014;28(4):287-302.

81. Mason OJ, Morgan CJ, Stefanovic A, Curran HV. The psychotomimetic states inventory (PSI): measuring psychotic-type experiences from ketamine and cannabis. Schizophrenia Research. 2008;103(1-3):138-42.

82. van Schalkwyk GI, Wilkinson ST, Davidson L, Silverman WK, Sanacora GJJoad. Acute psychoactive effects of intravenous ketamine during treatment of mood disorders: Analysis of the Clinician Administered Dissociative State Scale. 2018;227:11-6. 


\section{Figure 1. PRISMA Flow Chart of Study Selection}
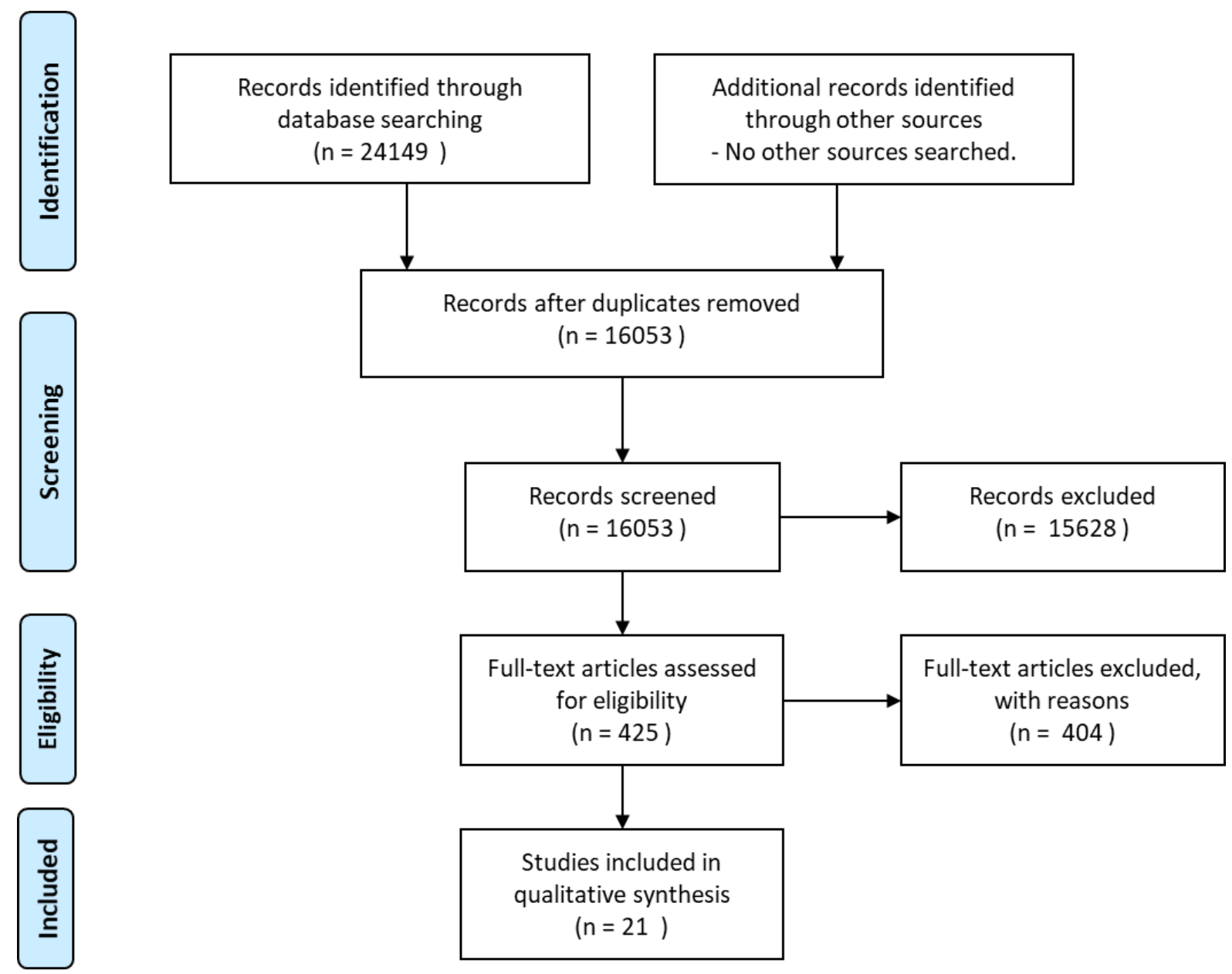
Table 1. Studies included in Systematic Review

\begin{tabular}{|c|c|c|c|c|c|c|c|c|c|c|}
\hline Author & Diagnosis & $\mathbf{N}^{*}$ & $\begin{array}{l}\text { Sex } \\
(\% \mathrm{f})\end{array}$ & Age & $\begin{array}{l}\text { Study } \\
\text { design }\end{array}$ & Ketamine efficacy & $\begin{array}{l}\text { Outcome } \\
\text { measure }\end{array}$ & $\begin{array}{l}\text { Outcome } \\
\text { measure } \\
\text { timepoint }(\mathbf{s}) * *\end{array}$ & $\begin{array}{l}\text { Psychoactive effects } \\
\text { measure }\end{array}$ & Key relevant findings \\
\hline \multirow[t]{5}{*}{$\begin{array}{l}\text { Aust et al., } \\
2019\end{array}$} & \multirow[t]{5}{*}{ MDD } & \multirow[t]{5}{*}{31} & \multirow[t]{5}{*}{52} & \multirow[t]{5}{*}{49.5} & \multirow[t]{5}{*}{ open label } & \multirow[t]{5}{*}{$\begin{array}{l}55 \% \text { treatment } \\
\text { response }\end{array}$} & MADRS & BL - 3 weeks & $\begin{array}{l}\text { 5D-ASC anxious ego } \\
\text { disintegration (AED) }\end{array}$ & $\begin{array}{l}\mathrm{R}(\mathrm{N}=17) \text { had lower 5D- } \\
\text { ASC AED scores than NRs } \\
(\mathrm{N}=14)\end{array}$ \\
\hline & & & & & & & MADRS & BL - 3 weeks & $\begin{array}{l}\text { 5D-ASC oceanic } \\
\text { boundlessness }\end{array}$ & No difference Rs and NRs \\
\hline & & & & & & & MADRS & BL - 3 weeks & $\begin{array}{l}\text { 5D-ASC visual } \\
\text { restructuralization }\end{array}$ & No difference Rs and NRs \\
\hline & & & & & & & MADRS & BL - 3 weeks & $\begin{array}{l}\text { 5D-ASC acoustic } \\
\text { alterations }\end{array}$ & No difference Rs and NRs \\
\hline & & & & & & & MADRS & BL - 3 weeks & $\begin{array}{l}5 \mathrm{D}-\mathrm{ASC} \text { altered } \\
\text { vigilance }\end{array}$ & No difference Rs and NRs \\
\hline \multirow{2}{*}{$\begin{array}{l}\text { Berman et al., } \\
2000\end{array}$} & \multirow[t]{2}{*}{$\mathrm{MDD} / \mathrm{BD}$} & \multirow[t]{2}{*}{7} & \multirow[t]{2}{*}{71} & \multirow[t]{2}{*}{37.0} & \multirow{2}{*}{$\begin{array}{l}\text { crossover, } \\
\mathrm{DB} \text {, rand }\end{array}$} & \multirow{2}{*}{$\begin{array}{l}\text { Significant } \\
\text { improvement } \\
\text { compared with } \\
\text { placebo }\end{array}$} & HDRS & $\mathrm{BL}-3$ days & VAS high & No association found \\
\hline & & & & & & & HDRS & $\mathrm{BL}-3$ days & $\mathrm{BPRS}+$ & No association found \\
\hline $\begin{array}{l}\text { Fava et al., } \\
2018\end{array}$ & MDD & 99 & 50 & 46.2 & $\begin{array}{l}\text { between, } \\
\text { DB, rand }\end{array}$ & $\begin{array}{l}\text { Significant } \\
\text { improvement } \\
\text { compared with } \\
\text { placebo }\end{array}$ & HAMD & $\begin{array}{l}\text { BL - } 1 \text { day \& } \\
\text { BL - } 3 \text { days }\end{array}$ & CADSS & No association found \\
\hline \multirow[t]{3}{*}{$\begin{array}{l}\text { Ionescu et al., } \\
2016\end{array}$} & \multirow[t]{3}{*}{$\begin{array}{l}\text { MDD + } \\
\text { suicidal } \\
\text { ideation }\end{array}$} & \multirow[t]{3}{*}{14} & \multirow[t]{3}{*}{79} & \multirow[t]{3}{*}{50.0} & \multirow[t]{3}{*}{ open label } & \multirow[t]{3}{*}{$\begin{array}{l}50 \% \text { remission of } \\
\text { suicidal ideation }\end{array}$} & HDRS-SI & BL - 3 weeks & CADSS & $\begin{array}{l}\text { Dissociation positively } \\
\text { correlated w/ suicidal } \\
\text { ideation }\end{array}$ \\
\hline & & & & & & & C-SSRS In & BL - 3 weeks & CADSS & No association found \\
\hline & & & & & & & C-SSRS Id & BL - 3 weeks & CADSS & No association found \\
\hline $\begin{array}{l}\text { Lapidus et al., } \\
2014\end{array}$ & MDD & 18 & 50 & 48.0 & $\begin{array}{l}\text { crossover, } \\
\text { DB, rand }\end{array}$ & $\begin{array}{l}44 \% \text { treatment } \\
\text { response }\end{array}$ & MADRS & $\begin{array}{l}\mathrm{BL}-24 \mathrm{~h} \\
\mathrm{BL}-24 \mathrm{~h}\end{array}$ & $\begin{array}{l}\text { CADSS } \\
\text { BPRS + }\end{array}$ & No association found \\
\hline $\begin{array}{l}\text { Moaddel et } \\
\text { al., } 2015\end{array}$ & MDD & 21 & 38 & 47.2 & open label & $\begin{array}{l}38 \% \text { treatment } \\
\text { response }\end{array}$ & MADRS & $\mathrm{BL}-230 \mathrm{~min}$ & CADSS & $\begin{array}{l}\mathrm{R}(\mathrm{N}=8) \text { had greater CADSS } \\
\text { scores than NRs }(\mathrm{N}=13)\end{array}$ \\
\hline
\end{tabular}




\begin{tabular}{|c|c|c|c|c|c|c|c|c|c|c|}
\hline Author & Diagnosis & $\mathbf{N}^{*}$ & $\begin{array}{l}\text { Sex } \\
(\% \mathrm{f})\end{array}$ & Age & $\begin{array}{l}\text { Study } \\
\text { design }\end{array}$ & Ketamine efficacy & $\begin{array}{l}\text { Outcome } \\
\text { measure }\end{array}$ & $\begin{array}{l}\text { Outcome } \\
\text { measure } \\
\text { timepoint (s) }\end{array}$ & $\begin{array}{l}\text { Psychoactive effects } \\
\text { measure }\end{array}$ & Key relevant findings \\
\hline $\begin{array}{l}\text { Niciu et al., } \\
2018\end{array}$ & $\mathrm{MDD} / \mathrm{BD}$ & 126 & 52 & 44.0 & $\begin{array}{l}1 \mathrm{x} \text { open } \\
\text { label, } 2 \mathrm{x} \\
\text { crossover } \\
(\mathrm{DB}, \text { rand) }\end{array}$ & $\begin{array}{l}\text { Not calculated as } \\
\text { secondary analysis }\end{array}$ & $\begin{array}{l}\text { HAMD } \\
\text { HAMD } \\
\text { HAMD } \\
\text { HAMD } \\
\end{array}$ & $\begin{array}{l}\text { BL }-7 \text { days } \\
\text { BL }-7 \text { days } \\
\text { BL }-7 \text { days } \\
\end{array}$ & $\begin{array}{l}\begin{array}{l}\text { CADSS } \\
\text { depersonalisation (DP) }\end{array} \\
\text { CADSS total } \\
\text { CADSS amnesia } \\
\text { CADSS derealisation } \\
\end{array}$ & $\begin{array}{l}\text { CADSS DP positively } \\
\text { associated w/ antidepressant } \\
\text { response } \\
\text { No association found } \\
\text { No association found } \\
\text { No association found }\end{array}$ \\
\hline $\begin{array}{l}\text { Phillips et al., } \\
2019\end{array}$ & MDD & 22 & 55 & 41.7 & $\begin{array}{l}\text { crossover, } \\
\text { DB, rand }\end{array}$ & $\begin{array}{l}\text { Significant } \\
\text { improvement } \\
\text { compared with } \\
\text { placebo }\end{array}$ & MADRS & BL -24 hours & CADSS & $\begin{array}{l}\text { Dissociation positively } \\
\text { correlated w/ antidepressant } \\
\text { response }\end{array}$ \\
\hline $\begin{array}{l}\text { Popova et al., } \\
2019\end{array}$ & MDD & 101 & 62 & 45.6 & $\begin{array}{l}\text { between, } \\
\mathrm{DB} \text {, rand }\end{array}$ & $\begin{array}{l}\text { Significant } \\
\text { improvement } \\
\text { compared with } \\
\text { placebo }\end{array}$ & MADRS & BL - 28 days & CADSS & $\begin{array}{l}\text { No difference between Rs } \\
(\mathrm{N}=70) \text { and } \mathrm{NRs}(\mathrm{N}=31)\end{array}$ \\
\hline $\begin{array}{l}\text { Shiroma et al., } \\
2014\end{array}$ & MDD & 14 & 0 & 54.1 & open label & $\begin{array}{l}92 \% \text { treatment } \\
\text { response }\end{array}$ & MADRS & BL - 12 days & CADSS & No association found \\
\hline $\begin{array}{l}\text { Sos et al., } \\
2013\end{array}$ & MDD & 27 & 56 & 43.7 & $\begin{array}{l}\text { crossover, } \\
\text { DB, rand }\end{array}$ & $\begin{array}{l}\text { Significant } \\
\text { improvement } \\
\text { compared with } \\
\text { placebo }\end{array}$ & MADRS & BL - 7 days & BPRS & $\begin{array}{l}\text { BPRS change negatively } \\
\text { correlated w/ antidepressant } \\
\text { response }\end{array}$ \\
\hline $\begin{array}{l}\text { Valentine et } \\
\text { al., } 2011\end{array}$ & MDD & 10 & 60 & 41.7 & $\begin{array}{l}\text { crossover, } \\
\text { SB, non- } \\
\text { rand }\end{array}$ & $\begin{array}{l}\text { Significant } \\
\text { improvement } \\
\text { compared with } \\
\text { placebo }\end{array}$ & HDRS & BL - 7 days & CADSS & No association found \\
\hline $\begin{array}{l}\text { Vidal et al., } \\
2018\end{array}$ & MDD & 10 & 60 & 51.0 & open label & $\begin{array}{l}80 \% \text { treatment } \\
\text { response }\end{array}$ & $\begin{array}{l}\text { MADRS } \\
\text { MADRS }\end{array}$ & $\mathrm{BL}-230 \mathrm{~min}$ & 5d-ASC & $\begin{array}{l}\text { BPRS }+ \text { not correlated with } \\
\text { outcome. Trend for an } \\
\text { association on day } 0 . \\
\text { No correlation found }\end{array}$ \\
\hline $\begin{array}{l}\text { Wan et al., } \\
2015\end{array}$ & MDD & 84 & 45 & 47.2 & $\begin{array}{l}2 \times \text { open- } \\
\text { label, } 1 \text { x } \\
\text { between } \\
\text { (DB, rand) }\end{array}$ & $\begin{array}{l}67 \% \text { treatment } \\
\text { response }\end{array}$ & $\begin{array}{l}\text { MADRS } \\
\text { MADRS }\end{array}$ & $\begin{array}{l}\text { BL - } 24 \text { hours } \\
\text { BL - } 24 \text { hours }\end{array}$ & $\begin{array}{l}\text { CADSS } \\
\text { BPRS + }\end{array}$ & $\begin{array}{l}\text { No difference between Rs } \\
(\mathrm{N}=56) \text { and NRs }(\mathrm{N}=28) \\
\text { No difference between Rs } \\
\text { and NRs }\end{array}$ \\
\hline $\begin{array}{l}\text { Wilkinson et } \\
\text { al., } 2019\end{array}$ & MDD & 44 & 60 & 46.7 & open label & $\begin{array}{l}46 \% \text { treatment } \\
\text { response }\end{array}$ & $\begin{array}{l}\text { QUIDS-SR } \\
\text { MADRS }\end{array}$ & $\begin{array}{l}\text { BL - } 4 \text { days } \\
\text { BL - } 4 \text { days }\end{array}$ & $\begin{array}{l}\text { CADSS } \\
\text { CADSS } \\
\end{array}$ & $\begin{array}{l}\text { No association found } \\
\text { No association found }\end{array}$ \\
\hline $\begin{array}{l}\text { Williams et } \\
\text { al., } 2018\end{array}$ & $\mathrm{MDD} / \mathrm{BD}$ & 12 & 43 & 41.3 & $\begin{array}{l}\text { crossover, } \\
\mathrm{DB} \text {, rand }\end{array}$ & $\begin{array}{l}50 \% \text { treatment } \\
\text { response }\end{array}$ & HAMD & $\mathrm{BL}-14$ days & CADSS & No association found \\
\hline
\end{tabular}




\begin{tabular}{|c|c|c|c|c|c|c|c|c|c|c|}
\hline Author & Diagnosis & $\mathbf{N}^{*}$ & $\begin{array}{l}\text { Sex } \\
(\% \mathrm{f})\end{array}$ & Age & $\begin{array}{l}\text { Study } \\
\text { design }\end{array}$ & Ketamine efficacy & $\begin{array}{l}\text { Outcome } \\
\text { measure }\end{array}$ & $\begin{array}{l}\text { Outcome } \\
\text { measure } \\
\text { timepoint (s) }\end{array}$ & $\begin{array}{l}\text { Psychoactive effects } \\
\text { measure }\end{array}$ & Key relevant findings \\
\hline $\begin{array}{l}\text { Zheng et al., } \\
2018\end{array}$ & $\begin{array}{l}\text { MDD/BD + } \\
\text { suicidal } \\
\text { ideation }\end{array}$ & 97 & 54 & 34.7 & open label & $\begin{array}{l}68 \% \text { treatment } \\
\text { response }\end{array}$ & $\begin{array}{l}\text { MADRS } \\
\text { MADRS }\end{array}$ & $\mathrm{BL}-26$ days & $\begin{array}{l}\text { CADSS } \\
\text { BPRS + }\end{array}$ & $\begin{array}{l}\text { Difference between Rs } \\
(\mathrm{N}=66) \text { and NRs }(\mathrm{N}=31) \\
\text { found only at third infusion. } \\
\text { No difference between Rs } \\
\text { and NRs }\end{array}$ \\
\hline $\begin{array}{l}\text { Taylor et al., } \\
2018\end{array}$ & $\begin{array}{l}\text { Social } \\
\text { Anxiety } \\
\text { Disorder }\end{array}$ & 18 & 39 & 29.7 & $\begin{array}{l}\text { crossover, } \\
\text { DB, rand }\end{array}$ & $\begin{array}{l}\text { Significant } \\
\text { improvement on } \\
\text { LSAS but not VAS } \\
\text { anxiety compared } \\
\text { with placebo }\end{array}$ & $\begin{array}{l}\text { VAS anxiety } \\
\text { LSAS }\end{array}$ & $\begin{array}{l}\mathrm{BL}-14 \text { days } \\
\mathrm{BL}-14 \text { days }\end{array}$ & $\begin{array}{l}\text { CADSS } \\
\text { CADSS }\end{array}$ & $\begin{array}{l}\text { No association found } \\
\text { No association found }\end{array}$ \\
\hline $\begin{array}{l}\text { Dakwar et al., } \\
2014\end{array}$ & $\begin{array}{l}\text { Cocaine } \\
\text { Dependence }\end{array}$ & 8 & 13 & 47.5 & $\begin{array}{l}\text { crossover, } \\
\text { DB, rand }\end{array}$ & $\begin{array}{l}\text { Not calculated as } \\
\text { secondary analysis }\end{array}$ & $\begin{array}{l}\text { URICA } \\
\text { URICA }\end{array}$ & $\begin{array}{l}\text { BL - } 24 \text { hours } \\
\text { BL - } 24 \text { hours }\end{array}$ & $\begin{array}{l}\text { HMS } \\
\text { CADSS }\end{array}$ & $\begin{array}{l}\text { HMS positively associated } \\
\text { w/ URICA as mediator } \\
\text { CADSS positively correlated } \\
\text { w/ URICA, but not mediator }\end{array}$ \\
\hline $\begin{array}{l}\text { Dakwar et al., } \\
2018\end{array}$ & $\begin{array}{l}\text { Cocaine } \\
\text { Dependence }\end{array}$ & 18 & 44 & 49.8 & $\begin{array}{l}\text { crossover, } \\
\mathrm{DB} \text {, rand }\end{array}$ & $\begin{array}{l}\text { Significant } \\
\text { improvement } \\
\text { compared with } \\
\text { placebo }\end{array}$ & $\begin{array}{l}\text { composite } \\
\text { improvement } \\
\text { score } \\
\text { composite } \\
\text { improvement } \\
\text { score } \\
\text { composite } \\
\text { improvement } \\
\text { score }\end{array}$ & $\begin{array}{l}\text { BL - } 2 \text { weeks } \\
\text { BL - } 2 \text { weeks } \\
\text { BL - } 2 \text { weeks }\end{array}$ & $\begin{array}{l}\text { CADSS } \\
\text { HMS } \\
\text { NDES }\end{array}$ & $\begin{array}{l}\text { CADSS positively correlated } \\
\text { w/ global improvement, but } \\
\text { not mediator } \\
\text { HMS positively associated } \\
\text { w/ global improvement as } \\
\text { mediator } \\
\text { NDES score positively } \\
\text { correlated w/ global } \\
\text { improvement, but not } \\
\text { mediator }\end{array}$ \\
\hline $\begin{array}{l}\text { Krupitsky \& } \\
\text { Grinenko, } \\
1997\end{array}$ & $\begin{array}{l}\text { Alcohol } \\
\text { Dependence }\end{array}$ & 108 & 0 & 36.5 & open label & $\begin{array}{l}66 \% \text { treatment } \\
\text { response }\end{array}$ & $\begin{array}{l}\text { length of } \\
\text { remission }\end{array}$ & $\mathrm{BL}-1$ year & $\begin{array}{l}\text { Intensity of negative } \\
\text { experiences }\end{array}$ & $\begin{array}{l}\text { Intensity of negative } \\
\text { experiences positively } \\
\text { correlated w/ remission }\end{array}$ \\
\hline
\end{tabular}

1997 correlated w/ remission

\% f: percentage of females, MDD: Major Depressive Disorder, BD: Bipolar Disorder, DB: double-blind, rand: randomized, MADRS: Montgomery Asberger Depression Rating Scale, HDRS: Hamilton Depression Rating Scale, HDRS-1: Hamilton Depression Rating Suicide Subscale, C-SSRS. Columbia Suicide Severity Rating Scale, C-SSRS In: Columbia Suicide Severity Rating Intensity Subscale, CSSRS Id: Columbia Suicide Severity Rating Ideation Subscale, 5D-ASC: 5-Dimensional Altered State of Consciousness Rating Scale, VAS: Visual Analogue Scale, BPRS: Brief Psychiatric Rating Scale CADSS: Clinician Administered Dissociative States Scale, R: Responders, NR: Non-responders M: Mean, SD: Standard Deviation, * number of participants used to calculate key relevant findings 